\title{
Mutậwğ̂sith
}

\begin{tabular}{|c|c|c|}
\cline { 2 - 3 } \multicolumn{1}{c|}{ JURNAL } & HUKUM & ISLAM \\
\hline Vol. 3. No. 2 (2020) 07-12 & E-ISSN: : 2723-4681 & P-ISSN: 2722-2764 \\
\hline \multicolumn{2}{|c|}{ Published online on the journal's website: } \\
http://jurnal.iailm.ac.id/index.php/mutawasith
\end{tabular}

\section{Analisa Hukum Islam dalam Meninggalkal Shalat Jum'at pada Masa Pandemi Corona Virus Disease 2019 (Covid-19)}

\author{
Irdlon Sahil
}

Sekolah Tinggi Agama Islam Syaichona Moh. Cholil Bangkalan, Indonesia irdlonsahil88@gmail.com

\begin{tabular}{|c|c|c|}
\hline Received: & Revised: & Published: \\
\hline 12-11-2020 & 27-11-2020 & $15-12-2020$ \\
\hline \multicolumn{2}{|c|}{ DOI: https://doi.org/ 10.47971/mjhi.v3i2.238 } \\
\hline
\end{tabular}

\begin{abstract}
This study discusses the legal status of leaving Friday prayers during the Corana Virus pandemic. Based on the source of Islamic law; al-Qur'an, hadith and ijma' ulama. In this study there are four conclusions, first, the scholars agreed that the law of Friday prayer is mandatory for people who are affected by the law of taklif and are in a state of pain, fear of illness, fear of life and property, rain, very cold or very hot weather and the outbreak of a disease such as coronavirus. Second, it is permissible not to perform Friday prayers if there is udzur in the way. It's part of the waiver in the goal of setting the law at a secondary level of need that turns into a primary need because the spread of this virus has been life-threatening. Third, it is obligatory to obey the leader, as long as the policy is not contrary to Islamic law. To measure the conformity of the leader's policy with sharia by referring to a benefit. Fourth, as long as the udzur syar'i is still struck, leaving Friday prayers is no limit.
\end{abstract}

Keywords: Law, Friday Prayers, Covid-19.

\section{Abstrak}

Penelitian ini membahas tentang status hukum meninggalkan shalat Jum'at pada masa pandemi Virus Corana. Berdasarkan sumber hukum Islam; al-qur'an, hadis dan ijma' ulama. Dalam penelitian ini ada empat kesimpulan, pertama, para ulama sepakat bahwa hukum shalat Jum'at wajib bagi orang yang terkena hukum taklif dan berada dalam kondisi sakit, takut sakit, kwatir terhadap jiwa dan harta, hujan, cuaca sangat dingin atau sangat panas dan mewabahnya suatu penyakit seperti virus corona. Kedua, boleh tidak melaksanakan shalat Jum'at jika ada udzur yang menghalangi. Ini bagian dari keringanan dalam tujuan penetapan hukum pada tingkat kebutuhan sekunder yang berubah menjadi kebutuhan primer karena penyebaran virus ini telah mengancam keselamatan jiwa. Ketiga, wajib mentaati pemimpin, selama kebijakannya tidak bertentangan dengan syariat Islam. Untuk mengukur kesesuaian kebijakan pemimpin dengan syariat dengan mengacu pada sebuah kemaslahatan. Keempat, selama udzur syar'i masih melanda, meninggalkan shalat Jum'at tidak ada batasan. 
Kata Kunci: Hukum, Shalat Jum'at, Covid-19.

\section{PENDAHULUAN}

Aktivitas ibadah berupa shalat merupakan kewajiban setiap orang Islam, baik lakilaki ataupun perempuan, pelaksanaannya dengan perbuatan, perkataan dan berdasarkan syarat-syarat dan rukun yang tertentu dimulai takbir sampai mengucapkan salam. Urgensi shalat dalam Islam berkaitan dengan sendi agama, sebagaimana Rasulullah SAW bersabda, Shalat itu adalah sendi agama, barang siapa mengerjakannya berarti ia telah menegakkan tiang agama. Dan barang siapa yang meninggalkan berarti ia telah merobohkan agama. Diantara shalat yang wajib itu adalah shalat Jum'at yang hukumnya fardhu 'ain bagi tiap-tiap orang muslim mukalaf, laki-laki, berakal dan sehat. ${ }^{1}$

Jum'at menjadi suatu hari yang sangat spesial bagi orang Islam, sebab shalat yang didirikan pada hari Jum'at memiliki nilai mulia disisi Allah SWT, disamping keunggulan harinya. Shalat Jum'at yang harus dilakukan secara berjamaah atau bersama-sama dan tidak boleh sendiri-sendiri seperti yang boleh dilakukan pada jenis shalat wajib yang lain. Kewajiban shalat fardhu baik yaumiyah maupun usbuiyyah yang merupakan shalat wajib itu harus dilaksanakan sesuai waktu yang ditentukan. Artinya dalam waktu normal dan tidak ada halangan yang dianggap rukshakh/keringanan dalam syariat, maka posisi shalat tersebut boleh ditinggalkan. Maka dalam keadaan tidak normal boleh mengganti waktu atau bahkan mengganti jenis shalat dengan shalat lainnya seperti shalat Jum'at boleh diganti dengan shalat Dzuhur pada masa pandemi ini. Karena Islam tidak memperbolehkan pemeluknya untuk membunuh, membahayakan dirinya dan Islam menyuruh menghindari hal-hal yang menyebabkan pada kematian. Dalam hal ini Allah SWT berfirman Q.S. an-Nisâ/4: 29. Artinya: "Dan janganlah kamu membunuh dirimu. Sesungguhnya Allâh adalah Maha Penyayang kepadamu".2

Seperti yang telah diketahui bahwa Kasus covid-19 sudah menjadi pandemi global. Kemunculan virus ini terdeteksi awal di Wuhan, China, pada Desember tahun 2019, yang kemudian berkembang pesat sehingga banyak korban jiwa di seluruh dunia, termasuk juga di Indonesia. Pradanti mengatakan, salah satu penyebab cepatnya penyebaran virus yang segolongan dengan sars dan MERS CoV ini adalah banyaknya riwayat perjalanan internasional. Dalam perkembangan terakhir, total kasus yang terkonfirmasi positif Covid-19 terus mengalami peningkatan yang sangat signifikan, khususnya di Indonesia. Per 2 Oktober 2020 kasus di Indonesia telah mencapai

\footnotetext{
${ }^{1}$ H. M. Ridwan Hasbi, "Paradigma Shalat Jum'at Dalam Hadits Nabi" Jurnal Ushuluddin Vol. Xviii No. 1, (Januari 2012), No. 70.

${ }^{2}$ H. Mahmudin. "Rukhsah (Keringan) Bagi Orang Sakit Dalam Perspektif Hukum Islam", Jurnal IImiah Al Qalam, Vol. 11, No. 23, (Januari-Juni) 2017, 75.
} 
295.499. ${ }^{3}$ Oleh karena itu upaya penanganan virus ini harus diambil demi keselamatan dan kemaslahatan umat. Menanggapi hal tersebut, salah satu solusi yang diterapkan untuk memutus mata rantai penyebaran dan penularan Covid-19 ini adalah dengan menerapkan social distancing atau menjaga jarak dengan minimal satu meter dari orang yang sedang mengalami gejala yang diduga terindikasi Covid-19. ${ }^{4}$

Implementasi social distancing dan juga anjuran menggunakan masker pada dasarnya adalah cara menjaga jarak sosial yaitu dengan menghindarkan diri dari keramaian atau tempat perkumpulan yang melibatkan banyak orang. Rupanya situasi Covid-19 ini hampir sama dengan terjadinya wabah thāun di masa lalu dimana dalam hal ini Imam Bukhari pernah menyatakan bahwa masalah thāun adalah jenis penyakit yang bentuknya tidak seperti penyakit biasa dan penyakit ini juga menimpa kebanyakan manusia dengan berbagai cara yang berbeda. Thāun juga tidak hanya menimpa dunia Islam saja, tetapi juga dialami seluruh dunia. ${ }^{5}$

Dengan melihat bahayanya Covid-19 serta memandang aturan pemerintah dan pemangku agama di Indonesia, maka semua ibadah termasuk juga ibadah shalat Jum'at, harus dilakukan di rumah dan tidak boleh dilaksanakan di tempat ramai seperti di mushalla, masjid atau tempat lainnya. Ketentuan ini diharapkan sebagai cara memutus mata rantai Covid-19 yang dinilai memakan banyak korban. Adapun kewajiban shalat Jum'at yang pada dasarnya wajib dilaksanakan di dalam masjid secara berjamaah, tentu menjadi hambatan dalam pemutusan mata rantai Covid-19, karena melibatkan banyak massa yang terdiri dari para jamaah shalat Jum'at itu. Maka pemerintah dan para pemangku agama yang diwakili oleh Majlis Ulama Indonesia sepakat mengeluarkan Fatwa Nomor 14 Tahun 2020 tentang Penyelenggaraan Ibadah dalam Situasi Terjadi Wabah Covid-19. Isi kebijakan pemerintah, fatwa MUI, dan maklumat organisasiorganisasi Islam lainnya adalah meniadakan pelaksanaan shalat Jum'at, berjamaah, Tarawih dan shalat hari raya serta tidak mengadakan perkumpulan yang melibatkan banyak orang.

Hanya saja ketika shalat Jum'at dilakukan di rumah dan bukan di dalam masjid, maka status shalat Jum'at akan diganti dengan shalat Dzuhur, hal ini dikarenakan pelaksanaan shalat Jum'at harus dikerjakan dengan minimal terdiri dari empat puluh orang laki-laki yang memenuhi persyaratan keabsahan shalat Jum'at tersebut. ${ }^{6}$ Melihat permasalahan ini, bagaimana analisa hukum meninggalkan shalat Jum'at pada masa pandemi Covid-19. Penelitian ini bertujuan ingin mengetahui status hukum meninggalkan shalat Jum'at dalam masa pandemi global atau pada masa mewabahnya

\footnotetext{
${ }^{3}$ Gugus Tugas Covid-19, 2020.

${ }^{4}$ Muhammad Arsad Nasution, "Efektivitas Rukhshah Dalam Pelaksanaan Ibadah Masa Pandemi Covid-19", Yurisprudentia: Jurnal Hukum Ekonomi, Vol. 6 No. 1 (Juni 2020), 67.

${ }^{5}$ Saifuddin Zuhri Qudsy, Ahmad Sholahuddin, "Kredibilitas Hadis Dalam Covid-19: Studi Atas Bażl Al-Mā'ūn Fi Fadhli Al-Thāun Karya Ibnu Hajar Alasqalany", Al Quds : Jurnal Studi Alquran Dan Hadis, Vol. 4, No 1, (2020), 5.

${ }^{6}$ Lihat H. M. Ridwan Hasbi, "Paradigma Shalat Jum’at Dalam Hadits Nabi", 77.
} 
Covid-19 di negara Indonesia dengan segala permasalahan dan kebijakan pemerintah tentang aturan pelaksanaan shalat Jum'at, yakni dilaksanakan di rumah dan tidak boleh dikerjakan di dalam masjid atau tempat lainnya yang melibatkan banyak masa dikarenakan Covid-19 diyakini akan lebih mudah menyebar ketika terjadi kerumunan manusia. $^{7}$

\section{METODE}

Jenis penelitian ini adalah studi kepustakaan atau literature study yakni sebuah penelitian yang didasarkan pada sumber-sumber kepustakaan berupa buku, artikelartikel, jurnal dan pendukung lainnya dalam bentuk sumber primer dan sekunder. ${ }^{8}$

Sumber Data

Data primer dalam pembahasan ini adalah analisa hukum Islam dalam meninggalkan shalat Jum'at pada masa pandemi Corona Virus Disease 2019 (Covid-19). al-Qur'an, hadits Nabi SAW serta pernyataan para ulama melalui kitab-kitab klasik. Data Sekunder yang digunakan adalah kitab-kitab fiqih dari ulama empat madzhab, fiqih sunnah, buku-buku, artikel-artikel, jurnal dan pendukung lainnya.

Teknik Analisis Data

Adapun untuk mengetahui bagaimana analisa hukum Islam dalam meninggalkan shalat Jum'at pada masa pandemi Corona Virus Disease 2019 (Covid-19), penulis mengumpulkan sumber primer, sekunder serta pendukung lainnya untuk diproses dengan cara deskriptif analisis.

\section{HASIL DAN PEMBAHASAN}

\section{A. Hukum Shalat Jum'at}

Setiap orang Islam wajib melaksanakan shalat lima kali dalam sehari, yang meliputi Subuh, Dzuhur, Ashar, Maghrib dan Isya'. Shalat harus sesuai dengan waktu yang telah ditentukan dan harus diikuti dengan disiplin. Namun di hari Jum'at, shalat waktu siang tidak lagi berupa shalat Dzuhur, akan tetapi diganti dengan shalat Jum'at, shalat ini diwajibkan bagi laki-laki dan harus dilakukan di masjid. ${ }^{9}$ Para ulama sepakat bahwa

\footnotetext{
7 Mukran H. Usman, "Syariat Islam Dan Kemaslahatan Manusia Di Era New Normal Pada Kegiataan Keagamaan Dan Pendidikan", Fenomena, Volume 12, No 1, (2020), 102.

${ }^{8}$ Ahmad Yani Nasution, "Ta'addud Al-Jum'at Menurut Empat Mazhab", Jurnal Mandiri: Ilmu Pengetahuan, Seni, Dan Teknologi, Vol. 1, No. 1, Juni 2017), 27.

9 Safiruddin Al Baqi \& Abdah Munfaridatus Sholihah "Manfaat Shalat Untuk Kesehatan Mental: Sebuah Pendekatan Psikoreligi Terhadap Pasien Muslim", Qalamuna - Jurnal Pendidikan, Sosial, Dan Agama | Vol. 11 No. 1, (Januari-Juni 2019), 88.
} 
hukum shalat Jum'at adalah fardhu 'ain bagi laki-laki yang sudah mencapai status mukallaf. Kewajiban ini didasarkan pada Al-quran, Sunnah dan Ijma' Ulama.

1. Dalil al-Qur'an

Dalam QS AI-Jum'at ayat 9, Allah SWT berfirman:

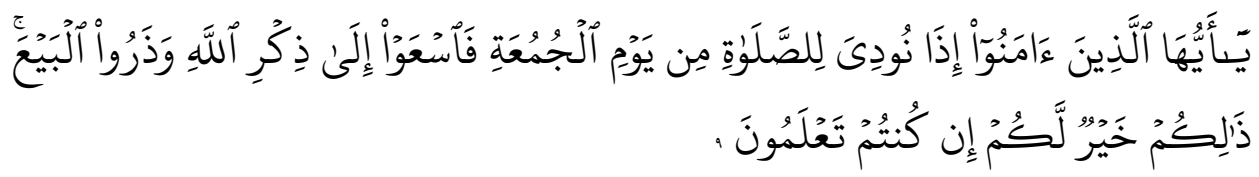

Artinya: "Wahai orang-orang beriman, apabila telah diseru untuk melaksanakan shalat pada hari Jum'at, Maka bersegeralah kamu mengingat Allah dan tinggalkanlah jual beli, yang demikian itu lebih baik bagimu jika kamu mengetahui."

Dalam ayat diatas Allah SWT melarang bertransaksi bagi yang berkewajiban shalat Jum'at pada waktu adzan telah dikumandangkan. Itu berarti ada konsekwensi hukum keharaman bagi mereka yang melanggarnya. Seruan dalam ayat tersebut ditujukan kepada orang-orang yang beriman saja. Dari pengertian ayat di atas, Allah SWT memberikan tanda bahwa kebanyakan manusia ketika mau bertransaksi seperti jual beli, utang piutang, gadai, dan sebagainya, sering tidak dilandasi dengan sifat jujur. Maka dalam bertransaksi harus ditanamkan rasa keimanan sehingga selalu berlaku jujur dan tidak merugikan orang lain. ${ }^{10}$

\section{Dalil Sunnah}

Hadits Nabi SAW yang diriwayatkan oleh Thariq bin Syihab dari Nabi shallallâhu 'alaihi wa sallam, bersabda, "Shalat Jum'at itu wajib bagi setiap orang Islam dengan cara berjama'ah, kecuali bagi empat golongan; hamba sahaya, perempuan, anak kecil dan orang sakit." Imam Abu Daud berkata, "Thariq bin Syihab benar-benar melihat Nabi shallallâhu 'alaihi wa sallam, namun belum pernah mendengar sesuatu pun dari beliau." (HR Abu Dawud). Dari keterangan hadis ini dapat diketahui bahwa posisi shalat Jum'at itu sangat tinggi karena selain punya status wajib, juga mempunyai nilai baik dari sisi keutamaan harinya. Maka tentu saja Nabi SAW memberitahukan kewajiban shalat Jum'at bagi orang-orang Islam.

3. Kesepakatan Para Ulama

a. Syarat Wajib Jum'at

Shalat Jum'at menurut mayoritas ulama hanya diwajibkan bagi setiap orang mukallaf yang laki-laki, dewasa, merdeka, sehat, mukim, dan bebas dari udzur termasuk semua madzhab yang empat. Hal ini bersandar kepada hadis nabi yang diantaranya adalah: "Salat Jum'at adalah kewajiban setiap orang Islam dengan berjamaah, kecuali empat orang: hamba sahaya, perempuan, anak kecil, dan orang yang sakit". ${ }^{11}$ Demikian juga Syeikh Nawawi berpendapat bahwa syarat wajib shalat Jum'at ada tujuh yaitu

10 Azminur Naila Najah, “Larangan Jual Beli Ketika Shalat Jum’at Dalam Kajian Tafsir Ahkam Fi AlMuamalah", Tahkim Vol. Xv, No. 1, (Juni 2019), 103.

${ }^{11}$ Ali Abubakar, "Reinterpretasi Shalat Jum'at: Kajian Dalil Dan Pendapat Ulama", Media Syariah, Vol. Xiii No. 2 (Juli-Desember 2011), 172. 
Islam, sudah baligh, berakal, laki-laki, merdeka yang sempurna, sehat tidak udzur, dan menetap atau bermukim meskipun empat hari.

Sedangkan menurut Wahbah Zuhaili, syarat wajibnya Jum'at adalah mukallaf atau baligh dan berakal, merdeka, laki-laki, bermukim atau tidak bepergian, tidak ada udzur seperti sakit dan lainnya, mendengar suara adzan. Bila dibandingkan antara dua pendapat di atas bahwa Wahbah al-Zuhaili tidak memasukkan syarat Islam, sedangkan imam Nawawi memasukkannya dalam sebagai urutan pertama. Sementara itu, imam Nawawi tidak memasukkan syarat mendengar panggilan adzan, sedangkan Wahbah alZuhaili memasukkannya sebagai syarat wajib Jum'at yang terakhir. Adapun syarat shalat Jum'at menurut Jumhur ulama ada tujuh. Hal ini sama dengan pendapat imam Nawawi di atas. $^{12}$

\section{b. Syarat Sah Shalat Jum'at}

Adapun syarat sah Shalat Jum'at adalah sebagai berikut:

a) Shalat Jum'at harus diadakan dalam satu tempat atau tempat tinggal baik di kota maupun di desa. Maka tidak sah mendirikan shalat Jum'at di tempat yang tidak merupakan daerah tempat tinggal, seperti di ladang atau jauh dari perkampungan para penduduk.

b) Shalat Jum'at harus dilaksanakan secara berjamaah. Adapun jumlah jamaah menurut sebagian ulama adalah empat puluh orang laki-laki dewasa dari penduduk setempat. Sebagian ulama yang lain berpendapat bahwa jumlah jamaah shalat Jum'at harus lebih dari empat puluh bahkan ada juga sebagian ulama yang lain yang berpendapat bahwa julam jamaah shalat Jum'at cukup dua orang saja. Hal ini karena sudah termasuk sebagai pengertian berjamaah.

c) Shalat Jum'at harus dikerjakan pada waktu tengah hari atau pada waktu zuhur. Hadis nabi dari jalur sahabat Anas ra., Rasulullah SAW. bersabda: Shalat Jum'at ketika telah tergelincir matahari." (H.R. Bukhari).

d) Hendaklah dilaksanakan setelah selesainya dua khutbah. Hadits tentang khutbah ini adalah diriwayatkan dari Ibnu Umar ra., Rasulullah saw. bersabda: khutbah pada hari Jum'at dengan dua khutbah dengan berdiri dan beliau duduk diantara kedua khutbah itu." (H.R. Bukhari dan Muslim). ${ }^{13}$

\section{B. Keringanan Shalat Jum'at Di Masa Pandemi}

Baru-baru ini dunia dibuat goncang oleh menyebarnya Covid-19. Hampir semua negara termasuk Indonesia sibuk mengantisipasi penyebarann virus mematikan ini, salah satu upaya dengan menerapkan lockdown atau menutup diri dan membatasi perkumpulan yang melibatkan banyak orang. Akibatnya seluruh aktivitas dan ibadah dilarang dilaksanakan secara beramai-ramai atau berjamaah termasuk pelaksanaan shalat Jum'at. Maka tentu pelarangan ini menuai pro-kontra di mata masyarakat,

\footnotetext{
${ }^{12}$ Masrukhin Muhsin, "Tata Cara Pelaksanaan Shalat Jum'at" (Studi Naskah "Sulûk Al-Jâddah Fî Bayân AlJum'ah" Nuansa, Vol. 9 No. 2 (Juli-Desember 2012), 363

${ }^{13}$ Lihat Ahmad Yani Nasution, "Ta'addud Al-Jum'at Menurut Empat Mazhab", 26.
} 
mereka banyak yang menyayangkan peraturan tersebut namun mereka sangat berharap situasi ini segera selesai. Apalagi Apalagi keadaan sosial dan ekonomi di masa pandemi ini sangat beragam dan fluktuasi. Hal ini membuat banyak masyarakat panik. Kepanikan dan kegelisahan yang terjadi di masyarakat terutama masalah penurunan pendapatannya, kesempatan oknum-oknum menyampaiakan provokasi untuk melakukan berbagai kegiatan tidak terpuji, serta kejahatan hinggan menolak kebijakan pemerintah. ${ }^{14}$ Tetapi yang perlu diketahui bahwa ketetapan aturan dari pemerintah tentu saja memandang kepada kemaslahatan umum dan juga mengacu kepada dalildalil yang mendasari sesuai ketetapan syariah Islam.

Islam adalah agama yang moderat (wasathiyah), lurus, agama yang penuh dengan rahmat, agama yang sangat mudah, dan realistis (waqi'iyah). Hal Inilah yang membedakan agama Islam dengan agama lainnya. Bagian kecil dari keistimewaan Islam ini adalah kesesuaiannya dengan segala keadaaan. Ketentuan yang berlaku umum dalam keadaan normal namun juga tidak menafikan keadaan-keadaan tertentu yang di luar kebiasaan normal. Agama Islam memberikan kelonggaran beragama dalam keadaan yang sempit atau sulit.

Tidak ada keraguan lagi bahwa memelihara atau eksistensi jiwa itu lebih didahulukan daripada memelihara cabang dari agama. Sikap mendahulukan kepentingan memelihara jiwa daripada cabang dari memelihara agama bisa dilihat dalam hukum-hukum yang terkait dalam keadaan terpaksa dan dalam keadaan darurat. Salah satu contoh puasa tidak diwajibkan bagi orang sakit atau lansia lemah dengan tujuan menghilangkan kesulitan dan memelihara jiwanya. Sama halnya tidak mengadakan shalat Jum'at dan jamaah untuk sementara yang tidak bermaksud lalai dari ketentuan agama. Keringanan tidak melaksanakan shalat Jum'at sekaligus tidak berjamaah bukanlah tidak melaksanakan shalat. Tetapi hal itu dapat diganti dengan shalat dzuhur dan shalat di rumah dan tetap dapat dilakukan secara berjamaah. Dalam hal ini kaidah fikih yang digunakan adalah; tidak boleh membahayakan diri sendiri dan membahayakan orang lain, menolak kerusakan lebih diutamakan daripada menarik kemaslahatan dan kemudharatan atau kesulitan harus dihindari dalam selama memungkinkan. ${ }^{15}$

Adapun dalil-dalil yang mendasari tentang keringanan untuk tidak mengadakan shalat Jum'at dan berjamaah saat tersebar wabah adalah sebagai berikut:

a) Dalil al-Qur'an

Ada beberapa ayat al-Qur'an yang menjadi pondasi berlakunya dispensasi (rukhshah) tersebut. Allah SWT. berfirman dalam QS. Al-Baqarah/2:173.

\footnotetext{
${ }^{14}$ Siti Khodijah Nurul Aula, "Peran Tokoh Agama Dalam Memutus Rantai Pandemi Covid-19 Di Media Online Indonesia", Living Islam: Journal Of Islamic Discourses, Vol. 3, No. 1 (Juni 2020), 141.

15 Muhamad Agus Mushodiq \& Ali Imron, "Peran Majelis Ulama Indonesia Dalam Mitigasi Pandemi Covid19; Tinjauan Tindakan Sosial Dan Dominasi Kekuasaan Max Weber", Salam; Jurnal Sosial \& Budaya Syar-i, Vol. 7 No. 5 (2020), 466.
} 


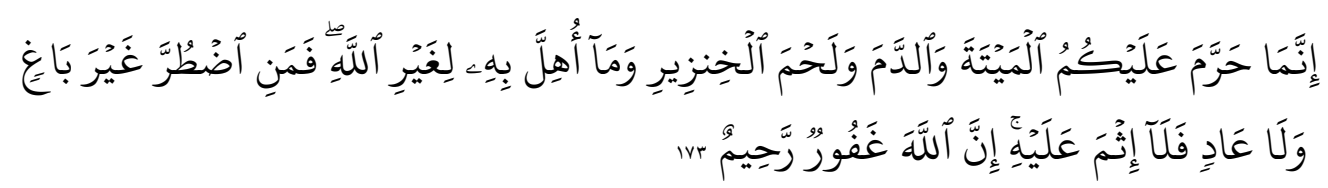

Artinya: "Sesungguhnya Allah SWT hanya mengharamkan bagimu bangkai, darah, daging babi, dan binatang yang ketika disembelih disebut selain nama Allah. Namun barangsiapa memakannya dalam keadaan terpaksa sedang dia tidak menginginkannya dan tidak (pula) melampaui batas, maka dia tidak berdosa sama sekali. Sesungguhnya Allah Maha Pengampun lagi Maha Penyayang" ${ }^{16}$

Kemudahan atau dispensasi merupakan salah satu prinsip penting dalam Islam dan sebagai anugerah dari Allâh SWT. Hal ini agar manusia tetap bersemangat dan tekun dalam menjalankan ajaran agama, terutama dalam situasi yang sangat sulit. Sebagaimana firman Allâh SWT. Q.S. al-Baqarah/2: 185.

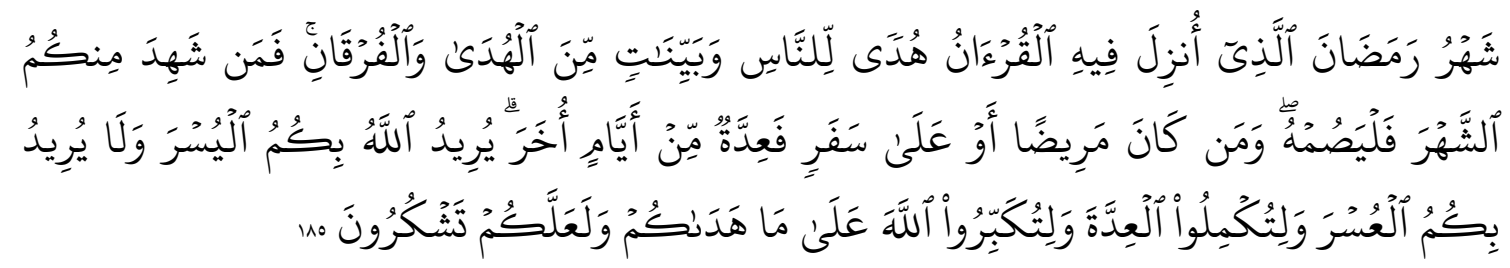

Artinya: "Bulan Ramadhan meupakan bulan yang di dalamnya diturunkan alQur'an sebagai petunjuk bagi manusia dan penjelasan-penjelasan mengenai petunjuk itu dan pembeda (antara yang hak dan yang bathil). Maka barangsiapa di antara kamu hadir (di negeri tempat tinggalnya) di bulan itu, maka hendaklah ia berpuasa pada bulan itu, dan barangsiapa sakit atau dalam perjalanan (lalu ia berbuka), maka (wajiblah baginya berpuasa), sebanyak hari yang ditinggalkannya itu, pada hari-hari yang lain. Allah menghendaki kemudahan bagimu, dan tidak menghendaki kesukaran bagimu. Dan hendaklah kamu mencukupkan bilangannya dan hendaklah kamu mengagungkan Allah SWT atas petunjuk-Nya yang diberikan kepadamu, supaya kamu bersyukur. ${ }^{17}$

Keterangan ayat di atas, Allah SWT memberikan keringanan bagi yang mempunyai udzur dalam menunaikan ibadah sesuai dengan sakit atau udzur yang mereka alami, supaya mereka dapat menunaikan ibadah kepada Allah SWT tanpa mengalami beban dan kesulitan. Misalnya posisi shalat yang dilakukan oleh orang yang sehat tentu berbeda dengan posisi salat orang yang sedang sakit. Syariah Islam memberikan kemudahan bagi mereka yang sedang mengalami sakit dan tidak mampu berdiri dengan diperbolehkannya melakukan shalat dengan posisi duduk, bahkan boleh berbaring bila sudah tidak mampu melakukan shalat dengan posisi duduk.

b) Sunah

Nabi Muhammad SAW mengajarkan agar orang sehat tidak bercampur dengan orang yang sedang menyandang penyakit menular. Beliau juga melarang agar tidak

\footnotetext{
${ }^{16}$ QS. Al-Baqarah: 173.

17 QS. Al-Baqarah: 185.
} 
masuk dalam suatu wilayah yang sedang terjangkit wabah atau penyakit menolar dan tidak keluar darinya jika berada di dalam wilayah yang sedang terjangkit wabah tersebut. Bahkan beliau tidak mengizinkan salah seorang dari bani Tsaqif yang menderita penyakit kusta untuk dibai'at secara langsung. Namun mereka dibai'at dengan utusan dan diminta untuk segera pulang. Hal ini dilakukan nabi sebagai bentul usaha untuk menghindar dari penyebaran penyakit yang menular. Dalam hal ini bahkan lebih penting untuk dilakukan dalam melarang perkumpulan atau melibatkan massa saat wabah sedang menyebar. Hadis ini memberikan penjelasan bahwa pentingnya menjaga kesehatan dan menghindari terjadinya resiko yang bisa menyebabkan terjangkitkan penyakit akibat lalai dalam kehati-hatian.

c) Pendapat Ulama Mazhab

Dari empat mazhab telah dijelaskan tentang keringanan meninggalkan shalat Jum'at dan jamaah dengan alasan sakit atau alasan takut sakit dan bentuk udzur lainnya. Mayoritas juga ulama menyatakan bahwa hukum melaksanakan sebuah dispensasi (rukhsah) berkaitan dengan keadaan mudharat atau kesulitan yang dihadapi. ${ }^{18}$ Menurut Imam al-Shawi terdapat udzur yang dapat menggugurkan kewajiban shalat Jum'at dan jamaah dalam mazhab Maliki, yaitu: jalan yang penuh dengan lumpur, terdapat hujan deras, sakit kusta, sakit yang memberatkan untuk pergi, sedang merawat orang sakit, sedang ada kerabat yang sakit keras, terdapat rasa takut atas hilangnya harta, takut ditangkap atau dipukul, termasuk juga takut untuk dibunuh atau dilukai.

Imam Ahmad bin Hamzah, imam Ramli memaparkan udzur yang bisa menggugurkan shalat shalat Jum'at dan jamaah adalah hujan deras, salju yang membasahi pakaian atau baju, jalan yang berlumpur, cuaca dingin atau sangat panas di waktu malam atau siang hari, sakit, lapar dan haus yang jelas, tertidur, tidak memiliki pakaian, mengkonsumsi makanan yang berbau keras yang tidak hilang meskipun sudah diusahakan untuk dihilangkan, takut pada keselamatan dan hartanya, merawat orang sakit, atau sibuk mencari obat bagi yang sakit, terdapat angin kencang pada malam hari, terdapat kejadian gempa, penyakit kusta, dan lain sebagainya. ${ }^{19}$

Imam al-Mardawi berpandangan bahwa yang menjadi udzur yang dapat meninggalkan shalat Jum'at dan jamaah adalah sakit, dimana hal ini juga disepakati oleh para ulama. Begitu juga jika terdapat rasa khwatir sakit, dihidangkan makanan dan nafsu untuk memakannya, atau rasa takut akan hilangnya harta, terdapat rasa takut kerugian dalam penghidupannya, misalnya menjaga kebun bahkan jika imam shalat terlalu panjang bacaannya. Masuk dalam kategori udzur juga adalah meninggalnya salah satu kerabat, atau sedang merawat orang yang sakit dan tidak ada yang bisa menggantikan,

\footnotetext{
18 Lihat Muhammad Arsad Nasution, "Efektivitas Rukhshah Dalam Pelaksanaan Ibadah Masa Pandemi Covid-19", 63.

19 Syamsuddin, "Keringanan (Rukhshah) Meniadakan Shalat Jum'at Dan Shalat Jama'ah Serta Kewajiban Menaati Ulul Amri", Al-'Adl, Vol. 13 No. 2, (Juli 2020), 174.
} 
terlalu mengantuk atau capek, kesulitan karena terdapat hujan, terdapat lumpur atau turun salju, terdapat angin kencang dan hawa dingin pada malam hari, serta makan makanan yang baunya tidak baik. ${ }^{20}$

Dari pemaparan para ulama mazhab di atas, dapat disimpulkan bahwa yang mendasari udzur shalat Jum'at adalah adanya kesulitan dengan segala bentuknya, hal ini sebagaimana penjelasan Nawawi sebagai berikut:

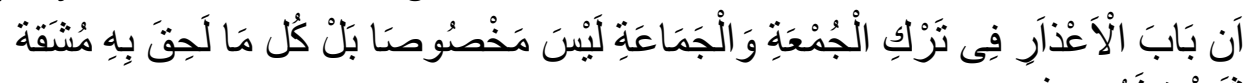

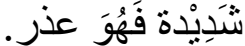

"Pembahasan tentang udzur dalam meninggalkan shalat Jum'at dan jamaah tidak terkhusus pada dalil hadis yang mendasarinya, akan tetapi setiap yang mendatangkan kesulitan yang sangat berat, termasuk sebagai udzur".

Maka sudah dianggap sebagai suatu kesulitan bila seseorang keluar untuk melaksanakan shalat di masjid dalam keadaan takut terjangkit penyakit atau virus dengan membawa sajadah masing-masing, memakai masker, shaf yang direnggangkan, kondisi tempat shalat harus dibersihkan dan semprot desinfektan setiap akan melaksanakan shalat. Kemudian setelah kembali ke rumah harus segera mencuci tangan, berganti baju atau mandi. khususnya jika virus tersebut benar-benar telah mewabah di daerah tempat tinggal.

d) Fatwa MUI tentang Shalat Jum'at pada Masa Pandemi Covid-19

Majlis Ulama Indonesia telah memaparkan dalil-dalil yang bersifat umum maupun khusus, baik berupa ayat-ayat al-Quran, hadis, dan kaidah fiqih. MUI melalui Fatwa Nomor 14 Tahun 2020 yang berisi tentang Penyelengaraan Ibadah dalam Situasi Terjadi Wabah Covid-19, menjelaskan kayfiyah pelaksanaan ibadah umat Islam. Diantara fatwa isi fatwa tersebut tentang pelaksanaan shalat Jum'at pada masa covid-19.

Berikut paparan isi fatwa tersebut; yang pertama pemerintah wajib memperketat setiap keluar-masuknya orang dan barang ke dan dari Indonesia kecuali para petugas medis dan import barang kebutuhan pokok serta keperluan emergency saja. Yang kedua, segenap umat Islam wajib mendukung dan mentaati kebijakan yang dikeluarkan oleh pemerintah. Yang ketiga, masyarakat Indonesia hendaknya bersikap proporsional dalam menyikapi penyebaran Covid-19 dan orang yang terpapar Covid-19 sesuai kaidah kesehatan. Karenanya, masyarakat diharapkan menerima kembali orang yang dinyatakan negatif atau yang dinyatakan sembuh. ${ }^{21}$ Untuk menguatkan fatwanya, MUI memakai hadits sebagai berikut: Dari Nabi saw sesungguhnya beliau bersabda: "Jika kalian mendengar suatu wabah di suatu wilayah, maka janganlah kalian memasukinya.

20 Lihat Syamsuddin, “Keringanan (Rukhshah) Meniadakan Shalat Jum'at Dan Shalat Jama'ah Serta Kewajiban Menaati Ulul Amri", 174.

${ }^{21}$ Lihat Siti Khodijah Nurul Aula, "Peran Tokoh Agama Dalam Memutus Rantai Pandemi Covid-19 Di Media Online Indonesia", 132. 
Tetapi jkalian berada di suatu wilayah yang sedang dilanda wabah, maka jangan kalian tinggalkan tempat itu." (HR. al-Bukhari). ${ }^{22}$

Keringanan atau dispensasi juga dimaknai sebagai hukum yang berdasarkan suatu dalil menyalahi dalil yang sudah ada pertama kali disebabkan adanya suatu fenomena atau udzur. Kebalikannya adalah azimah atau setiap hukum yang ditentukan oleh Allah pertama kali dalam keadaan umum. Keringanan adalah suatu yang diperbolehkan Allah dalam keadaan terpaksa sebagai keringanan bagi mukallaf dan menghindaarkan dari kesulitan Kemudia para ulama menyimpulkan satu kaidah fiqih yang disepakati dari ayat ini dan ayat-ayat serupa lainnya: "Sebuah kemudharatan dapat membolehkan hal-hal yang dilarang (diharamkan)".

Berdasarkan hal ini dapat diketahui bahwa mengambil keringanan tidak mengadakan shalat Jum'at dan jamaah untuk sementara yang diberlakukan di berbagai negara termasuk di Indonesia adalah pemberlakuan keadaan darurat untuk menghindari mudharat sesuai dan berdasarkan ayat-ayat tersebut. Tentu tujuannya untuk melindungi jiwa dan mencegah penyebaran wabah semakin meluas. Oleh karena itu, tidak boleh seseorang beranggapan bahwa apa yang diputuskan lewat fatwa dan kebijakan pemerintah sebagai perbuatan meremehkan shalat apalagi menganggap sebagai usaha untuk menjauhkan umat Islam dari masjid. Salah satu pilar dari asas ini ialah raf'u al-haraj (mengangkat kesulitan). Izzudin berkomentar, setiap perintah dan larangan syara' pada dasarnya untuk mewujudkan tujuan syariah, yang dikembalikan pada satu kaidah, "menarik suatu kemaslahatan dan menolak sebuah kerusakan". ${ }^{23}$

C. Sebab-Sebab yang Diperbolehkan Meninggalkan Shalat Jum'at

1. Orang-orang yang dibolehkan meninggalkan shalat Jum'at.

Sebenarnya hukum shalat Jum'at adalah wajib dan berupa fardu 'ain. Oleh karena itu dalam kondisi stabil tidak diperbolehkan meninggalkan shalat Jum'at tersebut. Akan tetapi boleh dalam keadaan terpaksa atau ada udzur yang syar'i. Ini adalah merupakan keringanan yang diberikan Allah kepada manusia. Menurut Sayyid Sabiq setidaknya ada enam golongan yang dianggap berhalangan dalam shalat Jum'at sehingga mereka tidak wajib shalat melaksanakan Jum'at, yaitu: pertama orang perempuan, kedua anak kecil, orang sakit yang berpotensi parah atau lambat sembuhnya bila melaksanakan shalat Jum'at, ketiga orang buta yang tidak ada orang yang menuntunnya dan orang yang sudah sangat tua dan pikun yang sulit menghadirinya ke masjid, keempat orang yang sedang dalam bepergian, kelima orang merasa takut ditangkap oleh penguasa zalim, atau orang yang takut kehilangan harta, jiwa, atau kehormatannya karena situasi negeri yang tidak aman dan yang ke enam orang yang berhalangan karena cuaca alam. Demikian juga termasuk semua udzur yang diberi keringanan oleh syara' untuk

\footnotetext{
22 Lihat Muhamad Agus Mushodiq \& Ali Imron, "Peran Majelis Ulama Indonesia Dalam Mitigasi Pandemi Covid-19; Tinjauan Tindakan Sosial Dan Dominasi Kekuasaan Max Weber", 466.

${ }^{23}$ Johari, Konsep Maslahah Izzudin Ibn Abdi Salam Telaah Kitab Qawa`ld Al-Ahkam Limashalih Al-Anam, Epistemé, Vol. 8, No. 1, (Juni 2013), 74.
} 
meninggalkan shalat jama'ah, misalnya karena kondisi hujan lebat, terjadi banjir air atau lumpur, longsor, kondisi udara sangat dingin atau sangat panas. Pelaksanaan shalat Jum'at tidak wajib dilaksanakan di dalam masid, namun cukup dikerjakan di rumah saja bila semua udzur di atas dialami oleh orang yang berkewajiban shalat Jum'at. ${ }^{24}$

Hal serupa juga diungkapkan oleh Ibnu Najim akan kebolehan tidak melaksanakan shalat Jum'at terlebih shalat berjamaah bagi orang tua yang sedang sakit-sakitan, hujan deras, menhindar dari pemimpin yang zalim dan takut dipenjara dan menghindar dari marabahaya yang bisa menyebabkan terjadinya keburukan seperti mewabahnya suatu penyakit. ${ }^{25}$ Orang sakit yang merasa sulit untuk menunaikan shalat berjama`ah dan shalat Jum'at atau khawatir sakitnya semakin parah dan atau menimbulkan semakin lambat sembuhnya, maka boleh tidak berjamaah di masjid. Ini berdasarkan hadist yang menceritakan keadaan Nabi SAW ketika beliau sedang mengalami sakit tidak hadir ke masjid, seraya nabi bersabda "Perintahkan Abu Bakar Ra., untuk mengimami shalat berjamaah. ${ }^{26}$ Namun orang sakit tetap berkewajiban menjalankan agamanya, selama akalnya masih berfungsi atau tidak gila, baik kewajibannya kepada Allah SWT seperti melaksanakan ibadah shalat, puasa, zakat, ataupun yang berkaitan dengan hak-hak manusia seperti wajibnya hukuman qhisas atau wajib memberikan nafkah kepada istri dan orang yang menjadi tanggungannya.

\section{Kewajiban mengikuti Peraturan Pemerintah}

Melaksanakan kegiatan baik kegiatan keagamaan maupun pendidikan jika aman dari suatu wabah tentu merupakan suatu hal yang sangat baik. Tetapi kenyataan yang menjadi masalah adalah ketika ada musibah atau penyakit wabah Covid-19 yang menular dan mematikan, dimana pemerintah melarang melakukan kegiatan dan aktivitas yang melibatkan banyak orang yang berkumpul dalam satu tempat dengan jumlah yang besar, maka sudah tentu dengan alasan kemaslahatan menyangkut keselamatan manusia menjadi tujuan prioritas utama. ${ }^{27}$

Bentuk ketaatan kepada Allah dan Rasulullah SAW. itu bersifat mutlak, sedangkan taat kepada ulul amri itu bersifat muqayyad atau bersyarat, artinya bersyarat kepada ketaatan kepada Allah dan Rasul-Nya. Hal itu selama perintah, aturan, dan ketentuan yang dibuat tidak menyimpang dari ketentuan syariat, tidak menghalalkan yang telah diharamkan dan tidak mengharamkan yang telah dihalalkan. Maka wajib hukumnya menaati ulul amri seperti halnya wajib taat kepada Allah SWT dan Rasulullah SAW. Allah memerintahkan untuk merujuk segala permasalahan kepada al-Quran dan sunah dan yang mengetahui cara merujuk kepada dua sumber ajaran Islam itu selain para ulama.

\footnotetext{
${ }^{24}$ Dulsukmi Kasim, Faham Tentang Larangan Shalat Jum'at Bagi Wanita Di Gorontalo, Al-Ulum: Volume 19 Number 1 (June 2019), 268.

25 Lihat Syamsuddin, “Keringanan (Rukhshah) Meniadakan Shalat Jum'at Dan Shalat Jama'ah Serta Kewajiban Menaati Ulul Amri", 173.

${ }^{26}$ Lihat H. Mahmudin. "Rukhsah (Keringan) Bagi Orang Sakit Dalam Perspektif Hukum Islam", 79.

27 Lihat Mukran H. Usman, "Syariat Islam Dan Kemaslahatan Manusia Di Era New Normal Pada Kegiataan Keagamaan Dan Pendidikan", 99.
} 
Tentunya hal ini menjadi dalil wajibnya bertanya kepada ulama dan keharusan mengikuti fatwanya. Al-Qur'an telah menjelaskan tentang kewajiban taat kepada pemimpin berpijak pada QS. An-Nisa/4:59

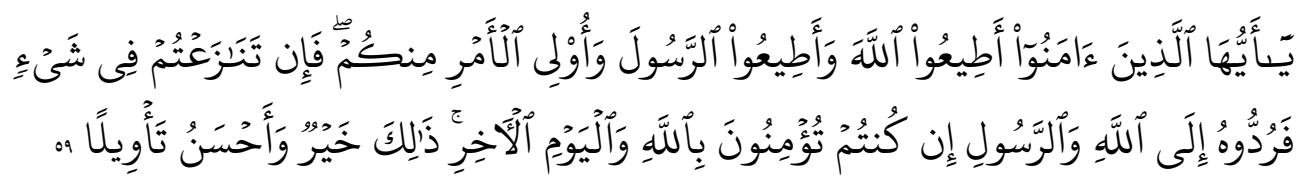

"Hai orang-orang yang beriman, taatilah Allah dan taatilah Rasul (Nya), dan ulil amri di antara kamu. Kemudian jika kamu berlainan pendapat tentang sesuatu, maka kembalikanlah ia kepada Allah dan Rasul, jika kamu benar-benar beriman kepada Allah dan hari kemudian. Yang demikian itu lebih utama (bagimu) dan lebih baik akibatnya".

Ayat ini memberikan penjelasan bahwa sudah menjadi kesepakatan para ulama bahwa wajib taat kepada ulul amri. Apalagi para ulama adalah pewaris para nabi. Hal ini tentunya menjadi dalil wajibnya mengkuti dan taat kepada fatwa ulama. Secara aspekaspek sosiologis, diantara tugas pokok para ulama adalah; Pertama, memberikan kerangka pokok yang sangat jelas yang bisa dikuti oleh masyarakat. Yang kedua, para ulama mempunyai peran sebagai pengawas, pengendali, dan penyalur opini terhadap perilaku dari masyarakat. Yang ketiga, mewakili masyarakat dalam berbagai interaksi atau hubungan dengan dunia luar. ${ }^{28}$

Sebuah kebijakan pemerintah benar atau tidak bergantung pada implikasinya terhadap rakyat. Jika kebijakan itu bisa berimplikasi pada kemanfaatan atau kemaslahatan rakyat, maka hal itu benar menurut syariat. Akan tetapi jika kebijakan tersebut berdampak pada kerugian atau mafsadat bagi rakyat, maka tentu bertentangan dengan syariat. Suatu kebijakan harus membuahkan kemaslahatan karena pemimpin bekerja bukan untuk dirinya, tetapi sebagai wakil dari rakyat yang dipimpinnya. Kemaslahatan itu dapat berupa kemanfaatan ataupun menghindarkan rakyat dari bahaya dan kerugian yang mengancam. Maslahah diambil sebagai konsep dalam kaitannya dengan memelihara agama, jiwa, akal, keturunan dan harta adalah sebuah kewajiban, dimana para ulama telah menetapkannya sebagai sebuah maslahat yang sifatnya darurat atau situasi sulit, yang bisa mengakibatkan tidak bahagia di dunia dan akhirat kelak, dan tentu akan kehilangan ketentraman dalam menjalani kehidupan di dunia. ${ }^{29}$

Arti kemaslahatan dapat bermakna kemanfaatan, kebaikan, dan kepentingan. Dalam hal ini ulama usul fiqih membagi kemaslahatan menjadi tiga berdasarkan kesesuaian dengan dalil-dalil yang ada yaitu maslahah mu'tabarah, mulghah, dan mursalah. Pengertian maslahah mu'tabarah adalah setiap maslahah yang secara tegas

\footnotetext{
28 Lihat Siti Khodijah Nurul Aula, "Peran Tokoh Agama Dalam Memutus Rantai Pandemi Covid-19 Di Media Online Indonesia", 138.

${ }^{29}$ Lihat Mukran H. Usman, "Syariat Islam Dan Kemaslahatan Manusia Di Era New Normal Pada Kegiataan Keagamaan Dan Pendidikan", 94.
} 
diakui oleh syariat dan telah ditetapkan ketentuan hukum untuk direalisasikan. Contohnya ancaman hukuman pada peminum khamar untuk memelihara akal, ancaman hukuman zina untuk memelihara kehormatan dan keturunan, serta ancaman hukuman mencuri untuk memelihara harta.

Adapun maslahah mulghah adalah sesuatu yang dianggap maslahah oleh akal tetapi dianggap palsu karena kenyataannya bertentangan dengan syariat dan bertentangan itu menunjukkan bukan maslahah di sisi Allah SWT. Misalnya anggapan baik menyamakan bagian warisan laki-laki dan perempuan. Sedangkan maslahah mursalah adalah sesuatu yang dianggap maslahah namun tidak ada ketegasan hukum yang mendukung ataupun yang menolaknya. Seperti menulis mushaf, membangun fasilitas sekolah dan perkantoran, peraturan lalu lintas, subsidi, penentuan jumlah gaji pegawai, penanganan wabah, dan banyak lainnya.

3. Batasan Meninggalkan Shalat Jum'at

Ibadah shalat merupakan salah satu media komunikasi antara manusia dengan Allah Subhanahu wa Ta'ala. Shalat juga merupakan rukun Islam yang kedua dan merupakan bentuk amaliah ibadah seorang hamba kepada penciptanya untuk mendekatkan diri kepadanya. Dalam menghadapi situasi pandemui Covid-19 yang telah memporak-porandakan seluruh aspek sosial masyarakat di dunia ini, kita seolah-olah kita dihadapkan ke dalam situasi yang setara dengan perang dunia, dimana kita harus berhadapan dengan situasi pandemi Covid-19 yang sangat bahaya dan bisa berpotensi mengancam semua aspek kehidupan, seperti kehidupan sosial, ekonomi, kesehatan, dan dapat membahayakan psikologis. Situasi yang dialami masyarakat Indonesia ini, tentu saja tidak jauh berbeda dengan apa yang dialami oleh masyarakat negara di luar Indonesia. ${ }^{30}$

Di sisi lain kedudukan shalat sangat penting dijaga, namu di lain sisi harus berhadapan dengan kondisi yang yang tidak mendukung. Adalah Covid-19 yang menyebabkan semua aktivitas "diliburkan" termasuk pelaksanaan shalat Jum'at. Kedudukan shalat sangat utama pada hari perhitungan amal seorang hamba, seperti dalam sebuah hadis yang diriwayatkan dari Abdullah bin Mas'ud radhiyallahu anhu, Rasulullah SAW bersabda:

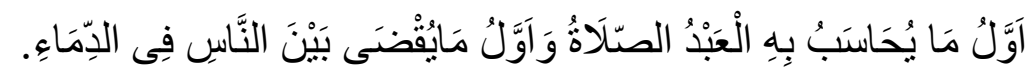

"Pertama kali yang dihisab oleh Allah SWT adalah shalat dan pertama kali yang diputuskan di antara manusia adalah yang berkaitan dengan darah." (HR. AnNasa'i)". ${ }^{31}$

Itu berarti amal seorang hamba yang pertama kali dihisab pada hari kiamat adalah shalatnya dan pertama kali yang diputuskan yang berkaitan dengan perkara yang terjadi

\footnotetext{
30 Karvina Dkk, Bunga Rampai Pandemi: "Menyingkap Dampak-Dampak Sosial Kemasyarakatan Covid19", (lain Parepare Nusantara Press, 2020), 66.

${ }^{31}$ An Nasa'i. No. 466
} 
di antara sesama manusia adalah masalah darah. Ibadah shalat merupakan hubungan antara manusia dengan Tuhannya. Sedangkan darah berkaitan dengan masalah yang terjadi antara sesama manusia. Namun demikian, terdapat banyak udzur yang memperbolehkan untuk tidak melaksanakan shalat Jum'at antara lain; hujan yang sangat lebat yang bisa membasahi pakaian dan menghalanginya melaksanakan shalat, terjadi turun salju, terdapat cuaca yang sangat dingin, sedang sakit yang menyulitkan ikut berjamaah di masjid, merasa kwatir ada gangguan keselamatan jiwa atau kehormatan diri dan hartanya. Dalam kondisi ini, Covid-19 tergolong salah satu udzur diperbolehkannya tidak menunaikan shalat Jum'at sebab ada kekawatiran menulari atau tertulari virus ketika ikut melaksanakan shalat Jum'at. Oleh karena itu meninggalkan shalat Jum'at tiga kali, atau bahkan lebih dari tiga kali jika penyebaran Covid-19 belum berubah dan kondisi tidak aman, maka hal itu dianggap dispensasi syara' yang pelakunya tidak divonis berdosa karena adanya udzur tersebut. ${ }^{32}$ Maka selagi tingkat rasio wabah ini masih tinggi, shalat Jum'at boleh ditinggalkan dan dikerjakan di rumah dengan diganti shalat Dzuhur, apalagi hal ini sudah masuk dalam kategori udzur syar'i dan tentu pula para tokoh agama di Indonesia telah mengeluarkan fatwa tentang kebolehan tersebut. Selain karena udzur, shalat Jum'at menurut mayoritas ulama adalah gantinya shalat dzuhur. ${ }^{33}$

\section{SIMPULAN}

Kesimpulan dari pembahasan di atas ada empat poin penting, pertama, para ulama sepakat bahwa hukum shalat Jum'at wajib bagi orang yang terkena hukum taklif dan berada dalam kondisi normal, misalnya sakit, takut sakit, kwatir terhadap jiwa dan hartanya, hujan, cuaca sangat dingin atau sangat panas dan mewabahnya suatu penyakit seperti virus corona. Kedua, boleh tidak melaksanakan shalat Jum'at jika ada udzur yang menghalangi, ini bagian dari keringanan yang diberikan oleh agama kepada pemeluknya dan termasuk maqashid syariah atau tujuan penetapan hukum pada tingkat kebutuhan sekunder yang berubah menjadi kebutuhan primer karena penyebaran virus ini telah mengancam pada keselamatan jiwa. Ketiga, wajib mentaati pemipin, ini berdasarkan al-Quran, sunnah, dan ijma' selama kebijakannya tidak bertentangan dengan syariat Islam. Untuk mengukur kesesuaian kebijakan pemimpin dengan syariat dengan mengacu pada sebuah kemaslahatan. Keempat, selama udzur syar'i masih melanda, meninggalkan shalat Jum'at tidak ada batasan, baik meninggalkan shalat Jum'at dengan jumlah tiga atau lebih dari tiga kali meskipun secara berturutturut.

\footnotetext{
32 Faried F Saenong Dkk, "Fikih Pandemi: Beribadah Di Tengah Wabah", (Nuo Publishing Jakarta Selatan, 2020), 17.

${ }^{33}$ Lihat Ali Abubakar, "Reinterpretasi Shalat Jum’at: Kajian Dalil Dan Pendapat Ulama”, 170.
} 


\section{DAFTAR PUSTAKA}

Abubakar, Ali, "Reinterpretasi Shalat Jum'at: Kajian Dalil Dan Pendapat Ulama", Media Syariah, Vol. Xiii No. 2 (Juli-Desember 2011).

Agus, Muhamad, Mushodiq \& Imron, Ali, "Peran Majelis Ulama Indonesia Dalam Mitigasi Pandemi Covid-19; Tinjauan Tindakan Sosial Dan Dominasi Kekuasaan Max Weber", Salam; Jurnal Sosial \& Budaya Syar-i, Vol. 7 No. 5 (2020).

Al Baqi, Safiruddin \& Munfaridatus, Abdah, Sholihah, "Manfaat Shalat Untuk Kesehatan Mental: Sebuah Pendekatan Psikoreligi Terhadap Pasien Muslim", Qalamuna Jurnal Pendidikan, Sosial, Dan Agama | Vol. 11 No. 1, (Januari-Juni 2019).

Arsad, Muhammad, Nasution, "Efektivitas Rukhshah Dalam Pelaksanaan Ibadah Masa Pandemi Covid-19", Yurisprudentia: Jurnal Hukum Ekonomi, Vol. 6 No. 1 (Juni 2020).

Faried F Saenong Dkk, "Fikih Pandemi: Beribadah Di Tengah Wabah", (Nuo Publishing Jakarta Selatan, 2020).

H. Mahmudin. "Rukhsah (Keringan) Bagi Orang Sakit Dalam Perspektif Hukum Islam", Jurnal IImiah Al Qalam, Vol. 11, No. 23, (Januari-Juni 2017).

Karvina Dkk, Bunga Rampai Pandemi:,"Menyingkap Dampak-Dampak Sosial Kemasyarakatan Covid-19", (Iain Parepare Nusantara Press, 2020).

Kasim, Dulsukmi, Faham Tentang Larangan Shalat Jum'at Bagi Wanita Di Gorontalo, AlUlum: Volume 19 Number 1 (June 2019).

Khodijah Nurul, Siti, Aula, "Peran Tokoh Agama Dalam Memutus Rantai Pandemi Covid19 Di Media Online Indonesia", Living Islam: Journal Of Islamic Discourses, Vol. 3, No. 1 (Juni 2020).

Muhsin, Masrukhin, "Tata Cara Pelaksanaan Shalat Jum'at" (Studi Naskah "Sulûk AlJâddah Fî Bayân Al-Jum'ah" Nuansa, Vol. 9 No. 2 (Juli-Desember 2012).

Mukran H. Usman, "Syariat Islam Dan Kemaslahatan Manusia Di Era New Normal Pada Kegiataan Keagamaan Dan Pendidikan", Fenomena: Jurnal Penelitian, Volume 12, No 1, (2020).

Naila, Azminur Najah, "Larangan Jual Beli Ketika Shalat Jum'at Dalam Kajian Tafsir Ahkam Fi Al-Muamalah", Tahkim Vol. Xv, No. 1, (Juni 2019).

Ridwan, H. M. Hasbi, "Paradigma Shalat Jum'at Dalam Hadits Nabi” Jurnal Ushuluddin Vol. Xviii No. 1, (Januari 2012).

Syamsuddin, "Keringanan (Rukhshah) Meniadakan Shalat Jum'at Dan Shalat Jama'ah Serta Kewajiban Menaati Ulul Amri", Al-'Adl, Vol. 13 No. 2, (Juli 2020).

Yani, Ahmad Nasution, "Ta'addud Al-Jum'at Menurut Empat Mazhab"Jurnal Mandiri: IImu Pengetahuan, Seni, Dan Teknologi, Vol. 1, No. 1, (Juni 2017).

Zuhri, Saifuddin, Qudsy, Ahmad Sholahuddin, "Kredibilitas Hadis Dalam Covid-19: Studi Atas Bażl Al-Mā'ūn Fi Fadhli Al-Thāun Karya Ibnu Hajar Alasqalany", Al Quds : Jurnal Studi Alquran Dan Hadis, Vol. 4, No 1, (2020). 
